\title{
Mummifying the Working Class: The Cultural Revolution and the Fates of the Political Parties of the 20th Century
}

\author{
Alessandro Russo*
}

\begin{abstract}
A number of prolonged political experiments in Chinese factories during the Cultural Revolution proved that, despite any alleged "historical" connection between the Communist Party and the "working class," the role of the workers, lacking a deep political reinvention, was framed by a regime of subordination that was ultimately not dissimilar from that under capitalist command. This paper argues that one key point of Deng Xiaoping's reforms derived from taking these experimental results into account accurately but redirecting them towards the opposite aim, an even more stringent disciplining of wage labour. The outcome so far is a governmental discourse which plays an important role in upholding the term "working class" among the emblems of power, while at the same time nailing the workers to an unconditional obedience. The paper discusses the assumption that, while this stratagem is one factor behind the stabilization of the Chinese Communist Party, it has nonetheless affected the decline of the party systems inherited from the 20th century.
\end{abstract}

Keywords: Cultural Revolution; working class; depoliticization; political parties

Rethinking the living legacies of the Chinese Cultural Revolution means to advance in a groping fashion in a heavy mist. Shrouded in the anathema of the official campaign to “thoroughly negate” (chedi fouding 彻底否定) the Cultural Revolution, ${ }^{1}$ for four decades it has been the object of unanimous execration, both in governmental and scholarly discourses, albeit with several exceptions at the grassroots. ${ }^{2}$ It is almost as if the Cultural Revolution had never happened.

* University of Bologna. Email: alessandro.russo@unibo.it.

1 The term appears in "Guanyu jianguo yilai dang de ruogan lishi wenti de jueyi" (On some questions concerning the history of the Party since the founding of the PRC), Renmin ribao, 1 July 1981, 1-7. The official campaign to "totally negate" the Cultural Revolution took place in earnest between 1984 and 1986, with dozens of editorials appearing in official newspapers calling for the total eradication of so-called "leftist" elements formerly associated with the Cultural Revolution.

2 For an accurate discussion of such exceptions, especially in China, see Gao 2008. For a recent reassessment of one key passage of the events, the Shanghai Commune, see Jiang 2014. 
Nonetheless, I would risk the hypothesis that a proper assessment of the 1960s in China not only is vital for finding new political paths but is also necessary for investigating the present day changes in forms of government around the world.

In re-examining the Cultural Revolution as a fount of possible intellectual resources, I will focus on two interwoven layers of legacies: the apparent stalemate in the visions and practices of modern egalitarian politics, and a profound change in the governmental circumstances of the contemporary social world. While the two plans have discrete logics and different temporalities, they manifest themselves in a web of entangled relations.

The first point is the most directly political. It concerns the possibility of rethinking egalitarian politics under the conditions of today's worldwide antiegalitarian governmental policies. How to discontinue the deadly repetition of the present rule of the world, which is based on the deletion of any political value of labour, the unlimited extension of social inequalities and the general trend towards a rampant militarization of contemporary societies? Without a thorough reassessment of the 1960s, I argue, the intellectual horizon of egalitarian politics will remain weak and inconclusive. Such a reassessment, moreover, certainly requires a deep rethinking of the most critical issues of modern politics, since the Cultural Revolution marked an impasse that reverberates retroactively on all egalitarian inventions, from the French Revolution onwards.

A second series of "legacies," although delayed and less obvious, lies in the substantial changes in contemporary governmental forms, namely the decline of party systems in the last decades of the 20th century. We must examine at least two paradoxes. Although the Cultural Revolution was the point of no return in a crisis faced by communist parties that started at least ten years before and is nowadays definitive for almost all of them, the largest communist party that has ever existed is in power in China today. Furthermore, far from marking the over-hastily proclaimed triumph of their competitors, the parliamentary parties, this crisis has indeed induced their inexorable decline also. My point is that re-examining the political stakes of the Cultural Revolution and their impasses is a prerequisite for investigating the vicissitudes of contemporary party systems, including the enigmatic persistence of a communist party in China.

\section{A Mass Experimental Political Laboratory}

To start with, a definition necessarily schematic is in order, given the magnitude of the topic. The Cultural Revolution was, in the last analysis, a mass political laboratory that tested the political value of the communist party. Its reach extended beyond China and indeed it was at the epicentre of the global political configuration of the "long sixties."

My working hypothesis is that the period initiated by the Sino-Soviet dispute of the late 1950s and brought to an end with the suppression of the Solidarity movement in Poland in the early 1980s, was a political configuration in the 
sense of a prolonged political process that was both unitary and manifold. ${ }^{3}$ The Cultural Revolution played a decisive role, not as a "revolutionary centre" that replaced the USSR, although somebody could have fantasized about that scenario at that time, but as the site that concentrated the most controversial political issues shared by the configuration as a whole.

The 1960s were a worldwide multifarious configuration that comprised countless political experimentations of any sort, whose core issue was an anxious rethinking about a possible political existence of workers. Worker politics was vital, for being the most problematic and obscure in modern politics. How is it possible to invent egalitarian relationships in industrial workplaces which are structurally the most despotic sites in the world? Can workers exist politically, since their social existence is confined to the sale of their labour-power as a commodity that is interchangeable like any other in the global market? The novelty of the 1960s lay in the fact that not only were these key political issues radicalized in the capitalist regimes, but they were also deeply questioned within the communist parties and the socialist states which had promised to completely overcome the conditions of wage slavery. Could the organizational conditions of the communist parties create a political role for workers, or were they only disciplinary rituals for obtaining obedience from subordinates? Were the socialist states an alternative to capitalism, or even the "historical" antecedent of communism, or were they just peculiar forms of domination?

Since such "impossible" questions were at the core of the 1960s, the horizon of the configuration was vast and encompassed an unprecedented wealth of political topics. Virtually everything that has to do with "the government of others" was the object of a series of inventive probes: the school, the university, men and women, the conflicts between generations, even the army, the asylums and the prisons. How to conceive of egalitarian relationships in such disparate fields? One key feature of the 1960s was the simultaneous appearance of a multiplicity of egalitarian experiments in all arenas of collective life and of one political nub the questioning of the political existence of the workers, even under the conditions of socialism.

This was the sign that no egalitarian agenda can elude the issue of the political destinies of modern wage slavery and, vice versa, that in order to invent egalitarian relationships in the workplace all other forms and modes of "governmentality" must be questioned, or, as Mao wrote, "it is only when the proletariat has liberated the entire human race that it can eventually liberate itself." 4 Even apart from the historical-political framework of a class-based vision of politics,

3 Russo 2016.

4 In response to the 1966 letter written by the first group of Red Guards founded at the Tsinghua University Middle School, Mao wrote: "Marx said: the proletariat must emancipate not only itself but all mankind. If it cannot emancipate all mankind, then the proletariat itself will not be able to achieve final emancipation. Will comrades please pay attention to this truth too." Taken from Schram 1974, 260-61. 
this issue is still vital and was even more urgent in the 1960s when it put into question the entire tradition of modern worker politics.

There is another essential reason that made worker politics the central issue of the 1960s. From the beginning of the mass phase, 1965-1966, the lowest common denominator of the political configuration of the 1960s was the existence of myriad organizations independent from the parties of the 20th century. In fact, the workers did not enter immediately on to the political scene of the 1960s. In many cases, as is known, the students organized politically first. However, the extra-party nature of that unprecedented mass political activism not only entailed, in different situations, a radical questioning of the value of the political parties of the 20th century as a whole, but also necessarily opened up the issue of the political subjectivity of the workers with respect to the party systems. ${ }^{5}$

Since the recognition of a degree of workers' political existence, although subjected to all sorts of restrictions, had been the prerequisite of the mass parties of the 20th century, the radical questioning of their political value in the 1960s aroused the workers' mobilization and inevitably raised the issue of the relationship between the "working class" and the communist parties. Below, I discuss how the aftermath of this process still has a decisive influence on the current crisis faced by political parties.

The popular narratives of the 1960 s often portray a somewhat turbulent, colourful youth movement which brought about a change of manners all over the world, including China, but which was undermined by the "terrorist utopian" movement to establish an "ideal society." Alternatively, it could even be said that what the Cultural Revolution set out to achieve at all costs was communism but what it eventually achieved was capitalism. The sarcasm, albeit malevolent, is not ungrounded, but as such, it remains fatalist or revanchist. An alternative path is to investigate the 1960 s and the Cultural Revolution as an experimental mass laboratory, which, I suggest, provides not only a way to examine any possible political legacy but also to formulate some conjectures on the relationship between the Cultural Revolution and contemporary capitalism.

Surely, after the exhaustion of previous intellectual frameworks, it is imperative to rethink a term that has become so obscure nowadays: "politics." In the common acceptation, "politics" usually refers to what we could better call "governmental subjectivities," that is, the actions, statements and intentions of those who strive to satisfy their desire to rule others. Such "enjoyment of power" corresponds to the well-known Weberian definition of politics. 6 "Politics as vocation" is, ultimately, driven by the wish to occupy superordinate positions at the various levels of collective life.

We assume instead that besides politics as a response to an alleged transcendent "calling" to exercise power over subordinates, other immanent forms of

5 The issue concerned both the global movements of the 1960s and the PRC specifically. See Russo 2016.

6 Weber 2015[1919], 136. 
politics can exist. In rare and discontinuous moments of the collective life, unexpected egalitarian inventions do appear, grounded on experimentation with new relationships among people in the most different fields. It is understood that "politics as calling" and politics as egalitarian inventions are, respectively, the rule and the exception. The former comprises few variations on the same theme, which is the satisfaction in deciding the life of others. The latter, instead, cannot but be a set of singular experiments, since nobody knows a priori what equality in the human world could be.

From this perspective, the political legacies of the 1960s that are worth examining are collective egalitarian experiments, the results of which are still to be explored, with the additional difficulty that these experiments were pushed by the urgency of rethinking the entire ideological and organizational tradition of modern egalitarian politics. They were political experiments that challenged the established visions of equality. Previous paradigms, such as the class-based vision of politics, underwent such a thorough critical enquiry that we are unable to adopt them as conceptual tools either for examining that political period or for investigating political phenomena in general.

The main testing ground - not the only one, but the subjective crux of the events - was the scrutiny of the organizations that, at that moment, were the undisputed "representatives of the working class." The communist parties proclaimed to embody a historical paradigm that guaranteed the political existence of the workers and of all possible egalitarian politics that had the "working class" as central. The experimental results of the 1960s proved, instead, that despite any alleged "historical connection" between the communist parties and the "working class," the political role assigned to the workers was fictitious and mostly reduced to the pathetic and tragic "man of marble" protagonist of Andrzej Wajda's film of the same name. ${ }^{7}$

As apparatuses, the communist parties were deeply integrated in the state forms of the 20th century. Since the late 19th century, the legalization of worker parties has played a critical role in the constitution of modern forms of government and in the generalization of the parliamentary system. Moreover, for several decades, from the 1920 s to the 1970 s, the existence of the socialist states was a decisive factor in curbing the inequalities inherent in the capitalist rule of the modern world.

Yet, the "long sixties" proved that the communist parties had much more in common with their "bourgeois" counterparts than what appeared to be the case during the ideological disputes and geopolitical contrasts of the Cold War. The socialist state "was not so different" from the capitalist one, "except for the ownership of the means of production," and without fresh political inventions it would have been much easier to pass from socialism to capitalism than to

7 Wajda's 1977 film, Man of Marble, was a profound questioning of the role of workers in Polish socialism, and anticipated the Solidarity movement. 
communism. These were Mao Zedong's 毛泽东 conclusive theses at the final stage of the Cultural Revolution. ${ }^{8}$

The issue of the relationship between the communist parties and the "working class" was decisive during the whole course of the political configuration. Key moments, such as the Shanghai "January storm" of 1967, the "hot autumn" of 1969 in Italy, or the Solidarity movement in Poland in 1980, each of which led to the creation, albeit in embryonic form and gropingly, of workers' organizations independent from the communist parties and often in sharp contrast with them, disproved that there existed an alleged "proletarian social basis" of the socialist states. It was in their relationship with the "working class" that the communist parties failed the test.

Here, we meet the first analytical difficulty. After the closure of that mass political laboratory, its experimental results were apparently suppressed and dispersed. In China, namely, they were in reality transformed and redirected towards completely different targets, targets that were indeed the very opposite of the original ones, through a process that needs careful consideration. It could be said that the experimental energies of the egalitarian political configuration, which had revealed the inconsistency of previous forms and modes of government, were then subsumed under new forms of government that were even more strictly hierarchized. It is not surprising that China has been at the epicentre of this process, since the thorniest issues of the worldwide configuration were concentrated in the Cultural Revolution.

This transformation, however, cannot be examined in terms of either "class restoration" or the "triumph of parliamentary democracy" over "totalitarianism." We lack solid categories for analysing the change from the egalitarian political configuration of the 1960 s to the current dominant governmental policies, so patently neo-oligarchical. Obviously, the latter, characterized by fundamentalist anti-egalitarianism, an obsession with hierarchies and the general contempt of rulers for ordinary people, are the reverse of the 1960s. However, on closer inspection, the transition is marked not by a radical discontinuity but rather by a redirecting, and surely a distortion, of the experimental results of those egalitarian political energies towards the new governmental circumstances.

The current supremacy of policies that extend inequalities, I argue, is indeed the reverse of the political subjectivities of the 1960s, but in the sense that it constitutes a "hollow imprint" of them. In other words, these changes are not only the result of the new ruling elites' ability to react to the political stakes of the 1960 s but they are also the new forms of domination that have been shaped through a unique "hollowing out" of the main issues of that political configuration. The changes in the contemporary party systems, I argue, are unreadable without considering this process.

Viewing the discontinuities in the Chinese Communist Party (CCP) after the Cultural Revolution through this lens, I argue that the subjective energies that 
allowed the Chinese elites to create a new governmental order capable of putting an end to the egalitarian experiments come essentially from those very experiments. The "new order" incorporated the results of the political test of the "previous disorders," and integrated them into a totally opposed subjective intention.

The mixed picture that this presents requires some explanation. The CCP, the first communist party to undergo the explosion of the party-class relationship crisis, has so far enjoyed unprecedented success and growth: nearly all other communist parties are virtually extinct. On the other hand, the system of parliamentary parties, which appeared to dominate following the crisis faced by the communist parties has, since the 1980s, suffered an irremediable decline. We can surmise then that this unequal development pertains to the same process of change experienced by the 20th-century political parties.

\section{The Ban of a Political Assessment}

The assumption that China's "new order" is the result of an "emptying out" of the previous experimental period must be examined from the beginning of the process. The final phase of the Cultural Revolution deserves special attention, both for having a momentous impact on the closure of the 1960s as a whole the "Chinese Thermidor" of 1976 - and for the protracted effect it has had on today that goes well beyond the Chinese boundaries. The strategy that allowed Deng Xiaoping 邓小平 to direct China's transition to reform and opening up is clearly at the root of the CCP's current stability. The global impact of Deng's strategy, however, is less discernible without first examining some crucial stages.

The first step in Deng's strategy, which I have examined elsewhere, ${ }^{9}$ can be traced back to a specific episode in 1975, a crucial year in China's political transition. China's "long sixties" was not brought to a close with a defeat exactly, but rather with the banning of political and intellectual assessment. One major prerequisite of the well-known governmental decree of "thorough negation," which effectively sealed the revolutionary decade in China, has been the preemptive prohibition of any self-reflection on the right and the wrong of the political events that took place in the preceding years.

In the autumn of 1975, at the height of an intense dispute with Mao, Deng lost the leading positions that he had acquired earlier that year. Although he was not formally dismissed until April 1976, restrictions had already been imposed on Deng's reform initiatives six months earlier. In the summer of 1975, the diverging views of Mao and Deng had become increasingly apparent, especially following the programmes developed by Deng with the support of his think tank, the State Council Political Research Office (Guowuyuan zhengzhi yanjiushi 国务院政治研 究室). ${ }^{10}$

10 The activities and the documents issued by this Research Office are described in Cheng and Xia 2004. 
The real breaking point, though, did not just spring from those programmes. It came also from Deng's categorical refusal to accept Mao's proposal in early October that Deng lead a national campaign focusing on what "had not worked" in the Cultural Revolution, literally yousuo buzu 有所不足. The episode, which has not attracted much scholarly attention, is not so clear-cut. Although Mao had in the previous weeks openly argued against Deng's "creative" and in fact misleading interpretations of his last political positions, he also repeatedly extended the invitation to Deng to direct the yousuo buzu campaign. ${ }^{11}$ Deng's refusal caused a temporary but serious weakening of his own position but, in the long term, proved crucial to his overall strategy.

The strong opposition posed by Deng was decisive, but its effectiveness was inversely proportional to an internal weakness of the Maoists themselves. Mao sought to overcome the failure among revolutionaries, himself included, to assess their own experience and their own limitations in the preceding events accurately. And, given that Mao had reopened, in new terms, a mass theoretical reflection on the socialist state form (the "dictatorship of the proletariat") in the previous months, as I discuss below, it would be reasonable to assume that Mao would have been able to push forward his proposals for the yousuo buzu campaign at that time. However, for his part, Deng, who had been totally refractory and hostile to the issues of that campaign, acted in a consistent manner, preventing the assessment proposed by Mao.

Mao's verdict on the Cultural Revolution was definitely positive, though with a critical reserve. He was convinced that the Cultural Revolution had opened up new possibilities for egalitarian mass activism, but he was also aware that it had led to destructive and self-destructive behaviour and that serious injustices were committed. There were different opinions, he maintained. Some complained about being unfairly abused, others just wanted to "settle scores" (suanzhang 算账). Only an open debate and research that extended across the entire country, he argued, could clarify the issues. ${ }^{12}$

We can speculate that a mass campaign at the end of 1975 on "what had not worked" in the Cultural Revolution would have likely been a large-scale movement, even dramatic and turbulent, involving high subjective tension. It was time to criticize politically several unjust treatments and to recognize the reasons why those unfairly accused had suffered. Yet, to distinguish between those who complained about unfair treatment and those who just wanted to "settle scores" would not have been an easy task.

A mass debate of that kind would have reopened innumerable personal cases, often very painful, and should have re-examined difficult and uncomfortable truths, involving the culpability of many people from all factions, the "rebels," the "loyalists," cadres at all levels, the army, and so on. Lastly, such a debate would have, inevitably, entailed even a re-examination of a number of Mao's

12 See Cheng and Xia 2004 and Russo 2013. 
political decisions during the decade. A reassessment would demand a deep capacity for collective criticism and self-criticism in order to discern the right from wrong, which new roads the mass activism had paved and which grave mistakes should not be repeated.

The proposal for a re-examination of the Cultural Revolution, starting with its "inadequacies," was in many respects the continuation of a major theoreticalpolitical movement, the campaign for the "study of the theory of the dictatorship of the proletariat," initiated by the Maoist group in the spring of 1975. The prerequisite for a reassessment of the decade was necessarily a thorough theoretical rethinking of this concept, which guided the relationship between the Party and the "working class." The Cultural Revolution had undermined the conceptual framework that supported the keystone of the communist organization and its governmental functions.

Late in 1974, Mao openly questioned the "dictatorship of the proletariat," a concept that still needed to be clarified he maintained, and launched an appeal to the "whole country" for a mass campaign of theoretical study. Without theoretical clarification, Mao considered the failure of the revolutionary endeavour to be almost inevitable. In short, an internal assessment of the Cultural Revolution required a broad theoretical horizon and the widest intellectual involvement possible of ordinary people in order to re-examine the key conceptual issues of revolutionary politics.

Despite his sharp opposition in October 1975 to the mass debate proposed by Mao, or rather consistently with his refusal to participate, Deng's strategic choices rested on a careful assessment of the Cultural Revolution. Clearly, here were two completely divergent perspectives: for Mao, the priority was to promote a mass rethinking of egalitarian politics; for Deng, the priority was to restore a governmental order, and any mass initiative would bring more disorder. Mao's aim was to promote a political self-assessment carried out by an indefinitely multiple set of egalitarian subjectivities, which he considered capable of "educat[ing] themselves by themselves" and "liberat[ing] themselves," we can infer, through their own mistakes. In contrast, Deng, for his part, aimed at reconstructing well-defined hierarchies that would be able to free themselves from any egalitarian initiatives of the masses, which he considered to be inherently anarchic.

Deng turned down Mao's proposal in autumn 1975 on the grounds that he was not the right person to lead the campaign as he had not participated in the Cultural Revolution. Clearly, this was not his primary reason, since not only was he well aware of the details of the Cultural Revolution but he also had clear thoughts on it. As the leader of such a campaign, he could have exerted a strong influence. Deng, though, was surely one of those who just wanted to "settle scores." In the previous months, he had openly laid down his strategy of "putting in order" (zhengdun 整顿), or as he said, "putting everything in order in all fields," which meant a drastic closure of all sorts of experiments that had been launched during the Cultural Revolution. A new assessment 
campaign, albeit in a self-critical mode, would have pre-emptively discredited the stance he would take in the near future for a "thorough negation."

Still, we should not take Deng's prescription for a "thorough negation" too literally. Although Deng's stance had been "thorough" when he refused to lead the assessment campaign in autumn 1975, when it came to the Cultural Revolution as a whole, the "negation" was anything but "thorough." Deng Xiaoping's position of strength lay in the fact that he was able to assess carefully the political results of the decade and use them "positively," albeit in an inverse sense, in the formation of a new hierarchical order.

The Cultural Revolution proved the inconsistency of revolutionary class politics as a method of government. Especially in the Maoist version, it required the constant testing, and in the last analysis, the reinvention of the political role of the workers. For Deng, instead, such constant testing was incompatible with the stability of the party-state. Yet, although Deng had "negated" the experimental results of the decade, he reworked and incorporated them in his own strategy.

\section{Depoliticizing the "Working Class"}

While the crux of the ideological differences lay in defining the relationship between the workers and the Party, the key organizational issues during the Cultural Revolution concerned the destiny of the socialist factory. In the first half of the 1970s, the Maoists launched a number of original and controversial initiatives in several industrial units, or danwei 单位. They maintained that the discipline and labour regimes in the socialist factory, lacking new political experiments, or, in their language, "newborn things" (xinsheng shiwu 新生事物), were not so dissimilar to those of the capitalist command.

Various experiments, like the workers' universities, the workers' theoretical groups, the participation of cadres in manual work and, conversely, the participation of workers in decision-making, were all aimed at deconstructing the "technical" hierarchies of the socialist factory and were critical of their presumed neutrality or objectivity. Such hierarchies, the Maoists argued, were not so different from those that made workers "dispossessed of mental powers of production" and enslaved for a lifetime to machine systems in the "big capitalist industry," as analysed by Marx.

One fundamental difference between socialism and capitalism is that under socialism, labour-power is not a commodity to be sold on the "free market." However, this point made the command within the industrial danwei even more complicated and equivocal, as often participation in an egalitarian collective project was enmeshed with relations of patronage. Moreover, the Maoists argued that the non-commodification of labour relations was only a temporary exception produced by socialism, one which it was quite possible to suppress, for re-establishing the ordinary rule of the capitalist government of the industrial work. A precise forecast indeed. 
All of these issues, which had emerged under the pressure of the unexpected appearance of independent workers' organizations in late 1966, created a serious political quandary that jeopardized the political and technical structure of the socialist factory. The initiatives promoted by the Maoists in the years that followed to deal with the crisis faced by the industrial danwei affected the overall organization of industrial work, namely the entanglement between the "technical division of labour" and the factory system of command. More essentially, they affected the conceptual relationship between the "working class" and the Party. ${ }^{13}$

Most of the technical and governmental cadres from the industrial danwei reacted spontaneously in defence of the status quo but were unable to restore the previous order, which the events of the decade had strongly called into question. There were tensions and conflicts between cadres and worker activists in some places but, overall, the situation in the factories in 1975 was not as chaotic and anarchic as Deng portrayed. Indeed, according to government sources subsequent to the reforms, there was considerable "productivity" at this time. ${ }^{14}$ The issues at stake involved radical political differences.

For the Maoists, it was vital "to clarify" fundamental theoretical issues and, at the same time, explore new forms of organization in the workplace that were open to the possibility of liberation from the established hierarchies. The most radical experiments even declared their urgent commitment to the long-term project of abolishing the divisions of labour. For Deng, on the other hand, the most urgent issue was how to rebuild stable hierarchies in the industrial workplace. This was the main objective behind his reiterated appeals in 1975 for "order."

Deng was aware that he could not simply restore the previous system of command but instead would have to create a new one. He also had to be able to map out a protracted strategy for effectively establishing "order," that is, to reestablish authority over workers in the factories. By considering the whole process of reform, it is possible to identify at least three basic consistent moves: the suppression of the Maoist experiments in the factories; the full commodification of labour-power; and the maintenance in the government discourse of the ideological reference to the "working class" and its "historical" connection with its "class vanguard," the Communist Party.

13 The most celebrated in those years were the "worker universities," the "workers' theoretical groups" and the regular participation of cadres in manual labour. To date, these experiments still lack detailed research. From the late 1950s, there was also the perspective of a thorough revision of the Soviet model of industrial management.

14 Although it is often taken for granted that the Chinese economy was a disaster during the ten years of Cultural Revolution, the available data from official sources reveal a very different picture. Cheng and Xia $(2004,590)$ cite a growth of GDP between 1974 and 1975 of 11.9 per cent and 15.1 per cent in industry. The figures for economic growth in 1975 given in Mao's official biography published by the Party school are different but equally positive: GDP 8.7 per cent; industry 15.1 per cent; agriculture 3.1 per cent (see Feng and Jin 2003, 1,752). While the Chinese economic statistics of the revolutionary era are generally considered as problematic, the Chinese economists estimate that GDP growth for 1967-1976 was 7.1 per cent. I am grateful to Cui Zhiyuan, professor of public policy and management at Tsinghua University, for discussing these data with me. 
The first obstacle to overcome was the set of experiments that had called into question the technical and political order of the industrial danwei and the related re-discussion of key theoretical issues. This prerequisite was achieved very early on. The Chinese "Thermidor" of October 1976 quickly shut down these experiments, declaring them to be just "conspiracies" of a small "gang" of usurpers. As for the moves to set up a "movement for the study of theory," the new government immediately proclaimed that these were a "nonsense" that was aimed at "defaming the dictatorship of the proletariat" and ultimately "overthrowing" it.

The next step, the commodification of labour-power, was inevitably more gradual but a crucial element for any "re-order." Once the "historical-political" command structure of the industrial danwei had been discredited, only the full commodification of labour-power could make effective the conjoint authority of the "technical division of labour" and "factory despotism." The process started in the late 1970s. It began first with the generalization of the piecework wage, praised as the highest achievement of the Marxist principle "to each according to his work" (an lao fenpei 按劳分配). ${ }^{15}$ In the 1990s, following the bloody suppression of the Tiananmen Square movement, the commodification of labour-power was fully established, with millions of internal migrant workers moving to form a massive precarious labour force. ${ }^{16}$

The celebrated transformation from the danwei, proclaimed obsolete and constrained by "old ideological dogmas," to the "enterprise" (qiye 企业), regulated by indisputable "technical" relationships, fully established the three basic conditions that Marx described as the foundations of the "big capitalist industry," namely, the rigid division between "manual and intellectual work," the despotism of the factory-barrack, and the "free market" of labour-power. The organization of the work at Foxconn, a "model factory" in contemporary China, which Pun Ngai's research describes in the most terrifying detail, ${ }^{17}$ essentially amounts to that of the capitalist factory analysed by Marx, but with an even greater despotism.

Such a definitive "putting in order" could not have been achieved without a further key element which was ultimately vital to the policy of reform. Mao had predicted that, "in China it would be easy to establish capitalism." 18 Except that, in order to establish capitalism in China, where the political role of workers had been so intensely disputed (actually even before the Cultural

15 In the meantime, the Chinese media were engaged in a widespread campaign of defamation against the workers, whom they portrayed as being dependent on the "iron rice bowl" (tiefanwan), that is, they were models of "laziness" and parasites feeding on public resources.

16 The suppression of the Tiananmen movement was one prerequisite for imparting an even more strictly "neoliberal" drive to the "reforms" in the months that followed. On this key passage of economic policies in the 1990s, see Wang 2003.

17 Pun and Chan 2012. See also the new extensive study by Pun, Chan and Selden 2015.

18 “Zai Zhongguo gao zibenzhuyi hen rongyi:” Mao 1998[1974], 415. 
Revolution), it was also essential to prevent any counter-effects, namely to impede the possibility that the workers might organize themselves politically. ${ }^{19}$

After all, it did happen in late 1966. The new rulers clearly perceived the danger, and all of them had in mind Marx's dictum: "The bourgeoisie creates its own gravediggers." Repressive measures would have been ineffective and hazardous, although when necessary the Chinese government has given ample proof of its readiness in this area, especially against workers. ${ }^{20}$ Pre-emptive measures based on a governmental discourse that leaves no doubt as to the state's intention to wield an iron fist against those who violate the rules have hitherto been more successful. These measures form part of an apparently contradictory but actually consistent strategy in which the upholding of the icon of the "working class" among the insignia of power paralleled and definitely supported its depoliticization.

A clarification on the concept of depoliticization can help my argument here. The de-politicization of the working class in China has been a lengthy and ongoing process. Its starting point, and its continuing raison d'être, is the closure of the relationships between the workers, the workplace and the Party. "Depoliticization" in this case is not meant as the waning of the amicus-hostis (friend-enemy) distinction in the Schmittian sense, but as the effect of a series of government policies aimed at voiding, politically, certain areas and sites where egalitarian experiments have taken place.

Here, it is necessary to make a distinction between a depoliticizationl (a weakening of the friend-enemy distinction) and a depoliticization2 (the closure of a set of egalitarian experiments). The homonymy partially matches the double acceptation of "politics" mentioned above, as the scope of governmental subjectivities or as mass inventions. Nonetheless, the relationship between them, as I will show, is not specular, but is in fact quite tortuous.

In the first case, de-politicization, meant as the absence of the regular operative principle of the "political" (the structural distinction between friend and enemy), concerns essentially the typical dynamics in the field of the governmental subjectivities of a given socio-historical world, especially at the level of the ruling elites. Rulers and would-be rulers of all ages are perpetually engaged in conflict with one another and also in weaving friendships according to the circumstances most conducive to their pursuit of "the conquest and the distribution of

19 As is well known, forms of resistance by workers, such as strikes, demonstrations and riots, are prevalent throughout China today. In his study on the protests of laid-off workers from SOEs, William Hurst documents that local authorities have a range of responses for dealing with such protests, from the most stringent to the most compromising, depending on the circumstances (Hurst 2009, 108-131). However, whilst grievances and claims concerning wages and welfare are, to varying degrees, tolerated, it is strictly unacceptable for any form of worker organization to claim a political role that positions itself against the "class vanguard" of the CCP. For updated documentation on workers' struggles, see the website of SACOM (Students and Scholars against Corporate Misbehaviour), http://sacom.hk.

20 The spur for the order for military intervention at Tiananmen Square in 1989, which came after the disbandment of the student movement, was the nascent formation of workers' autonomous organizations. For elements of analysis of the tragic episode, see Pozzana and Russo 2006. 
power." The Weberian definition of the essence of "politics as vocation" fits well with the Schmittian "categories of the political." In the case of depoliticization1, the mutual hostilities between competitors among the ruling elites are in a sense "deregulated" since they do not form clear-cut, opposing fronts.

Depoliticization2, on the other hand, involves different dynamics and stakes. It is the result of successful governmental policies that hinder and prohibit egalitarian inventions. Depoliticizing policies obviously take advantage of their internal weaknesses, which are intrinsic to their experimental nature. The very idea of political equality cannot but be the result of an endless series of precarious inventions, to be repeatedly tested, of new forms of collective life beyond the ordinary hierarchical regime. Egalitarian politics is therefore not reducible either to the a priori friend-enemy conflict or to the acts that "strive for the conquest and the distribution of power."

Equality can only exist as a set of inventive exceptions that alters the ordinary rituals of social hierarchies. Such exceptionality is thus also at the root of the rarity, fragility and discontinuity of the egalitarian inventions. They are always on the point of being "depoliticized" and any possible revitalization requires innovation. The "depoliticization of the working class" in China is therefore a depoliticization2, in that it has evolved from the series of measures that the coalition, guided by Deng, adopted to halt mass experimental politics and to restore a hierarchical discipline.

However, the new modes of disciplining labour in China are not just a restoration of the previous "socialist" ones. The conditions of wage labour in China are a paradigm of despotic capitalist command in the workplace, and the labour market is among the most "flexible" in the world. In the factories, a strictly Taylorist organizational form prevails: a fast turnover of staff is an organizational strongpoint at Foxconn. The Chinese "working class" of today has nothing in common with that of the industrial danwei.

Nonetheless, the new ruling elites in China have felt that it is necessary to maintain certain key terms from the previous hierarchical rituals, namely the affirmation of a special relationship between the "Communist Party" and the "working class" in the Chinese governmental discourse. In the most recent CCP Constitution, for instance, the first sentence proclaims, as in all the previous versions, that the Party is "the vanguard of the working class" (gongren jieji de xianfengdui 工人阶级的先锋队). ${ }^{21}$ Is it a flashy anachronism? Reform policies have received so much praise for their "pragmatism" and for having rejected what Deng called "ideological chit-chat" that it is hard to believe that the formula is merely a residue of a past that still performs the function of an obsolete liturgy.

The Chinese government is so eager to affirm technocratic values in labour relationships that one may wonder why it has not adopted a more "post-socialist" and more "modern" language. After all, the CCP must have acquired more 
up-to-date expertise in political propaganda. The reason why the CCP claims to be the "vanguard of the working class" cannot merely be because of the long pedigree of the formula or the fact that in socialist states it was often an effective way of maintaining authority over the workers. China's rulers know very well that they can no longer rely on outdated clichés; the Cultural Revolution demonstrated that the workers themselves disbelieved the disciplinary rituals of the "working class."

So, being neither nostalgia nor liturgy, the assertion that the CCP is "the vanguard of the working class" must therefore satisfy a critical need, which ultimately must be the prohibition of all forms of independent workers' organizations. It is true that all the above-mentioned steps in the process of depoliticization were conceived with this purpose in mind. Yet, a major concern of the new Chinese elites seems to be that without a clear-cut and definitive declaration, a depoliticization2 could be ineffective, or misunderstood. The insistence on pairing the "Chinese Communist Party" with the "working class" by the concept of political "avant-garde," which is the equivalent of political "organization," loudly proclaims to every single worker, and to anybody in China, that "I am the Chinese Communist Party, and thou shalt have no other political organizations before me."

If, for example, a dagongmei 打工妹 (a young female worker) at Foxconn, or one of her dagongzai 打工仔 (fellow males) would object that, after all, such a "vanguard" is nothing more than a peculiar organization of the capitalist command, she or he would be informed with plenty of doctrinal details that the "laws of historical development" today require capitalism. In the Chinese governmental discourse, capitalism is a condition of a "historical progress" that will lead to progressively advanced stages of socialism until the day the very "development of the productive forces" will also bring communism. The first paragraph of the CCP Constitution ends with the assertion that the "highest ideal" and the "ultimate goal" of the Party is to "realize Communism" (shixian gongchanzhuyi 实现共 产主义).

In China, it is understood perfectly by all - both by those who write and those who must read these formulas - that they mean only one thing: independent political organizations are unacceptable, especially for the workers, who are under special surveillance in contemporary China. Anyone violating this principle knows full well what the consequences of doing so are. Far from being an ideological remnant, such formulas continue to have a very real and powerful impact today. They establish depoliticization 2 as the basic principle of government in China, although there is no knowing how long it may continue to be effective.

\section{The Resilience of the CCP and the Decline of the Parties of the 20th Century}

Lastly, a working track on the assumption, mentioned above, about depoliticization 2 in China as a process that has affected an overall change in contemporary party systems. The results have been clearly divergent. In the span of a few 
decades, with the exception of the CCP, almost all other communist parties have collapsed, including the founding father, the Soviet Union. However, parliamentary systems have been too hasty in claiming victory. Political sociologists have analysed their transformation into "catch-all parties," "parties without partisans," or even "postmodern parties." Richard Katz and Peter Mair have diagnosed the "cartelization" of the parliamentary parties, i.e. their transformation into organizations similar to the most opportunistic alliances among economic and financial oligarchies, and have concluded that the "mass party is over," or in other words, the party system of the 20 th century is obsolete. ${ }^{22}$

Moreover, Katz and Mair argue that intertwined with this "cartelization" is the depoliticization of the parliamentary parties, which has led to the loss of any real opposition from programmes, policies and organizational forms, and in some cases has even led to mutual "collusion." In a different theoretical framework, Wang Hui also considers depoliticization as key to analysing the exhaustion of ideological and political conflicts in the CCP in the era of reform. ${ }^{23}$ The concomitance between disparate and even opposite phenomena could explain the resilience of the CCP and the decline of the party system as a whole. However, the distinction between the two types of depoliticization may be helpful for clarifying the possible connections in the changes of the various party systems, as well as for hypothesizing the reasons behind their different states of health. I will limit myself to a few examples from Europe.

First, how to explain the different fates of the CCP and the Communist Party of the Soviet Union (CPSU)? I suggest that the parties of the Soviet bloc lacked the capacity of the CCP to make depoliticization2 the main source of their stabilization. They firmly suppressed all political innovations, from the Prague Spring to the Solidarity movement, but were unable to subsume the experimental results from these innovations into new forms of domination. The Polish events were the final evidence of the radical crisis that was occurring in the relationship between the communist parties and the "working class," a crisis that would undermine the overall stability of the Soviet-type states. Yet, the response of the Soviet-bloc governments only went so far as military repression; they failed to gain any "reactive" strength comparable to that which animated Deng's policies. Gorbachev's "perestroika" came too late and at a time when the system of government in the Soviet Union was so fragile and discredited that just a tiny coup would lead to its disintegration.

The Italian case is also emblematic. A similar decline, although more prolonged and with continuing consequences, hit the Italian Communist Party (PCI), which was once the largest communist party in a parliamentary regime. The PCI was at the fore of the movement to suppress the independent worker organizations that arose in the 1960s, proclaiming them to be homogeneous with "terrorism." It even made it a point of honour to sponsor the judicial 
harassment of Antonio Negri and other leaders of "Autonomia operaia"; 24 however, it failed to draw any "positive" lessons from these events. It congratulated itself on having achieved an apparent stability, but the very next day after the collapse of the Berlin Wall it hastily changed its name, removing the term "communist," and thus began a decline that has continued for more than two decades. A few months later, the Christian Democrats, which had been the main ruling party since the Second World War, also collapsed, and so followed the whole system of Italian parties of the so-called "First Republic."

The phenomena of "collusion" among the successors to those parties and the vanishing of differences between them, I suggest, are rooted in that passage. Despite the obvious disparities, we can conjecture that upstream of the depoliticizationl of Italian political parties there was a process analogous to that which determined the collapse of the Soviet-type ruling parties in the 1980s, that is to say, they failed to make depoliticization 2 the starting point for the reorganization of forms of control. The downfall of the USSR certainly played a major role in the disappearance of opposing politics between the PCI and the Christian Democrats and eventually in their shared ruin, since the very structure of the Italian parliamentary system after the Second World War was shaped by the geopolitics of the Cold War. Yet, the decline of the PCI, which was the first significant step in the undoing of the Italian party system, had begun much earlier and was primarily a consequence of the key issues at stake in the 1960s.

While taking account of the individual processes, I will now make some clarifications on the hypothesis about the global effect of depoliticization2 in China. The issue of worker politics has been crucial.

The end of the 1960s was marked in different national contexts by a strong anti-worker drive. Given the strong political nature of the configuration, its closure would require a strong re-disciplining of the workers. As noted above, one major episode that brought about that closure was the clampdown on the Solidarity movement in Poland in 1980; however, the first episode that marked the beginning of the end was the coup in China in 1976. It was not a coincidence that three of the members of the so-called "gang of four," the Maoist group arrested at that time, were among the most active leaders in the Shanghai "January storm": one had even initiated the first rebel workers' organization. In brief, from the second half of the 1970s, over the span of a few years, a series of counter-attacks was able to suppress the experiments that were aimed at rethinking the political status of workers.

While the main factor behind the defeat of those experiments was their inability to overcome their internal weaknesses - and political novelties are intrinsically fragile - it is significant that in key situations such as those in China, Poland and Italy, the communist parties acted with the same resolute intent to exact revenge on an insubordinate "social base." The different means of suppression, however, 
produced different outcomes. The singular force of Deng's leadership came from knowing the gravity of the crisis. His appeals in 1975 to the Party cadres to be "daring" in the task of "putting everything in order" bore the weight of a life-and-death issue. He was then able to develop a prolonged strategy of "thorough depoliticization" which culminated, as discussed above, with the stratagem of mummifying the concept of the "working class" and keeping that concept at the forefront of governmental insignia, while at the same time nailing the workers to the most stringent capitalist regime.

The way in which the CCP achieved a new governmental order demonstrated to the world a means of bringing the worker politicization of the 1960s to a close. Despite the preservation of elements of a "class" discourse, it soon became clear that the very concept of a "working class" had become a mere fiction in China. That this had occurred in a socialist country, notably one where there had been prolonged attempts to revitalize the political figure of the worker, could not but have profound consequences for all other contemporary governmental circumstances.

The announcement that China's rulers had found a way to obliterate the workers politically and to reduce their role in negotiations to mere sellers of their labour-power signalled a sea change to governments around the world. The modern ruling elites' old dream of a capital that does not need to negotiate anything political with the waged labour seemed to be coming true. The end of the worker as a political figure proclaimed the beginning of an era of non-negotiable capital.

Of course, this is just a perverse dream, but not without real consequences for government forms in general. Clearly, by "capital" we mean the control of wage labour, which is at the core of the governmental circumstances of the contemporary socio-historical world. ${ }^{25}$ The largest electronic manufacturing firm in China is at the epicentre of a general pattern of non-negotiable capital, which, while determined by its relationship with Apple, is actually a triarchy pivoting on the role of the CCP via the changes it triggered after the decade of the Cultural Revolution, and definitely as a reaction to it.

Such changes, I suggest, far from being mere technical adjustments of the industrial management, have deeply affected systems of government in the contemporary world, namely the role of the party systems. The turning point in China has determined the rapid decline of the parties of the 20th century because it has shattered their foundations. From the late 19th century onwards, the key point in the transition from "parties of notables" to "mass parties" was the recognition, to a certain degree and with all sorts of limitations, of the political existence of the workers. Any form of government, even Fascism and Nazism in specific ways, had to negotiate in some way or another its very existence with the workers. Particularly in parliamentary systems, the parties, besides the

25 The sadistic desire to obtain the unconditional obedience of the workforce extends in fact to everybody in the human world. For example, Terry Gou, the founder and CEO of Foxconn, compared workers to animals: "as human beings are also animals, to manage one million animals gives me a headache." He also proudly declared that he had hired experts from Taibei zoo to improve the training of Foxconn managers. See http://www.businessinsider.com/foxconn-animals-2012-1?IR=T. Accessed 31 July 2016. 
trade unions, were ultimately the main hub of negotiations between capital and labour. Since the 1980s, in contrast, workers have been erased politically and the ideal of a non-negotiable capital has been proclaimed, and thus the parties have lost their raison d'être. In other terms, "the mass party is over" since the previous forms of the political existence of workers are over.

The "negation" of the value of the political tests of the 1960s, in fact, did not restore the "labour movement" to the state it enjoyed, for example, in the 1950s. On the contrary, since the nub of the 1960s was the mass scrutiny of the organizational tradition of labour politics, to reject that experimental political passage has implied resetting to zero the value of everything that, for over a century, had made a series of extensive alterations to the structural circumstances of the capitalist rule of labour. It was because the 1960s were a prolonged political test of the historical horizon of the negotiations between capital and labour that the "negation" of the political 1960s resulted in the suppression of the possibility of even giving thought to that series of exceptions to capitalism that existed throughout the 20th century.

To summarize my arguments and draft some tentative conclusions, the depoliticization of the working class in China after the Cultural Revolution has had two orders of consequences.

One concerns a serious impasse in the horizon of egalitarian politics. Having banned any self-assessment of the decade and at the same time having distorted the experimental results, the "thorough negation" has left a radical uncertainty about the destiny of key concepts such as "working class" and even "communism" as resources for new egalitarian experiments. Can a class-based vision of politics be a reference for revitalizing worker politics, and how to conceive of the very idea of "communism" when both terms are icons of a governmental order that is hitherto one pillar of contemporary capitalism? The urgent need to rethink the intellectual and organizational conditions of politics is the most important legacy of the Cultural Revolution.

Equally urgent is the need to develop fresh ideas about contemporary governmental circumstances. Capitalism, on the one hand, no longer has any systemic alternative, a role socialist state planning appeared once to play. On the other hand, it does not correspond to one specific form of government but is compatible with any of them, whether they are parliamentary, communist, hereditary monarchies, or warlords. The current ideal of a non-negotiable capital involves the specific phenomenology of a multi-dimensional capital. No longer is there just "capital-parliamentarianism;" there is also "capital-communism," in which the name "communism" carries such weight and such a peculiar meaning!

\section{Acknowledgement}

I would like to thank Claudia Pozzana for having discussed at length the issues contained in this article, Patricia Thornton, Sun Peidong and Chris Berry for the tenacity of the project, and two anonymous referees for their helpful remarks. 


\title{
Biographical note
}

Alessandro Russo teaches sociology at Bologna University. He has recently completed a manuscript on Cultural Revolution and Revolutionary Culture.

\begin{abstract}
摘要: 文化大革命期间, 在许多中国工厂里,一系列持续的政治实验表明: 即 便共产党与 “工人阶级”之间存在所谓的 “历史性” 连接, 但是由于缺乏深 层次的政治再造，在社会主义，工人的角色被框定成惟上是从，跟资本主义 对工人的掌控甚少差别。文章认为，邓小平的改革的一个关键点是精准考 量上述实验结果，纵然将其推向相反方向，即更加严格地规训雇佣工人。 到目前为止, 这种做法的结果是缔造出一种国家话语, 在以“工人阶级”的 名义的权杖维续中, 它起到了重要作用, 同时将工人 “钉”于无条件服从的 境地。本文讨论的假设是, 虽然这个策略是中国共产党保持稳定的因素之 一, 但它也影响 20 世纪政党制度的衰落。
\end{abstract}

关键词: 文化大革命; 工人阶级; 去政治化; 政党

\section{References}

Cheng, Zhongyuan, and Xia Xingzhen. 2004. Lishi zhuanzhe de qianzou. Deng Xiaoping zai yijiuqiwu (The Prelude to the Historical Turning Point: Deng Xiaoping in 1975). Beijing: Zhongguo qingnian chubanshe.

Feng, Xianzhi, and Jin Chongji. 2003. Mao Zedong zhuan, 1949-1976 (Biography of Mao Zedong, 1949-1976). Beijing: Zhongyang wenxian chubanshe.

Gao, Mobo. 2008. The Battle for China's Past. London: Pluto Press.

Hurst, William. 2009. The Chinese Worker after Socialism. New York: Cambridge University Press. Jiang, Hongsheng. 2014. La Commune de Shanghai et la Commune de Paris. Paris: La Fabrique.

Katz, Richard S., and Peter Mair. 1995. "Changing models of party organization and party democracy: the emergence of the cartel party." Party Politics 1(1), 5-28.

Katz, Richard S., and Peter Mair. 2009. "The cartel party thesis: a restatement." Perspectives on Politics 7(4), 753-766.

Mao, Mao [Deng Rong]. 2000. Wo de fuqin Deng Xiaoping: "wenge” suiye (Deng Xiaoping, My Father: The "Cultural Revolution” Years). Beijing: Zhongyang wenxian chubanshe.

Mao, Zedong. 1998[1974]. "Guanyu lilun wenti de tanhua yaodian, 1974 nian, 12 yue” (Main points of the talk on the theoretical problems, December 1974). In Zhonggong zhongyang wenxian yanjiushi (eds.), Jianguo yilai Mao Zedong wengao (Manuscripts of Mao Zedong after 1949), Vol. 13. Beijing: Zhongyang wenxian chubanshe, 413-15.

Murphy, Timothy S. 2005. "Introduction." In Antonio Negri, Books for Burning: Between Civil War and Democracy in 1970s Italy. London: Verso Books.

Pozzana, Claudia, and Alessandro Russo. 2006. "China's new order and past disorders. a dialogue starting from Wang Hui's analyses.” Critical Asian Studies 3, 329-351.

Pun, Ngai, and Jenny Chan. 2012. "Global capital, the state, and Chinese workers: the Foxconn experience." Modern China 38, 383-410.

Pun, Ngai, Jenny Chan and Mark Selden. 2015. Morire per un i-Phone. (Ferruccio Gambino and Devi Sacchetto (eds.)). Milan: Jaca Books.

Russo, Alessandro. 2013. "How did the Cultural Revolution end? The last dispute between Mao Zedong and Deng Xiaoping, 1975.” Modern China 39(3), 239-279.

Russo, Alessandro. 2016. "The sixties and us.” In Alex Taek-Gwang Lee and Slavoj Žižek (eds.), The Idea of Communism 3: The Seoul Conference. London: Verso, 137-178. 
Schram, Stuart (ed.). 1974. Mao Tse-Tung Unrehearsed. Talks to the People: Talks and Letters: 1956-71. Harmondsworth: Penguin.

Wang, Hui. 2003. China's New Order. Cambridge, MA: Harvard University Press.

Wang, Hui. 2006. "Depoliticized politics, multiple components of hegemony, and the eclipse of the sixties.” Inter-Asia Cultural Studies 7(4), 683-700.

Weber, Max. 2015[1919]. "Politics as vocation." In Tony Waters and Dagmar Waters (ed., trans.), Weber's Rationalism and Modern Society. New York: Palgrave Macmillan.

Zhongguo gongchandang. 2012. Gongchandang zhangcheng (Constitution of the Chinese Communist Party). Beijing: Renmin chubanshe. 